\title{
Kyrönjoen vesistöalueen rikkipitoiset viljelysmaat
}

\author{
RAIMo ERViö \\ Maatalouden tutkimuskeskus, Maantutkimuslaitos, 01300 Vantaa
}

\section{Cultivated sulphate soils in the drainage basin of river Kyrönjoki}

RAIMo ERviö

Institute of Soil Science, Agricultural Research Centre, 01300 Vantaa

\begin{abstract}
About $260 \mathrm{~km}^{2}$ of cultivated soil in the drainage basin of river Kyrönjoki in Western Finland was mapped for acid sulphate soils on the basis that they included sulphate-sulphur more than $100 \mathrm{mg} /$ litre soil and their $\mathrm{pH}\left(\mathrm{H}_{2} \mathrm{O}\right)$ was/below 5.0. The area was about $19 \%$ of the whole cultivated area and was situated mainly at $15 \mathrm{~m}$ to $45 \mathrm{~m}$ above the sea level.

More than 600 soil samples on 220 sites were taken from top soil $(0-20 \mathrm{~cm})$, from subsurface $(50-70 \mathrm{~cm})$ and from subsoil below the ground water level $(150-300 \mathrm{~cm})$. The sulphate-sulphur, $\mathrm{Ca}, \mathrm{Mg}, \mathrm{K}, \mathrm{Fe}, \mathrm{Al}$ and $\mathrm{Mn}$ were analysed in extract of acid ammonium-acetate ( $\mathrm{pH} 4.65)$.

In the aerobic middle layer were the highest amounts of $\mathrm{S}, \mathrm{Fe}$ and $\mathrm{Al}$, the highest conductivity and likewise the lowest $\mathrm{pH}$ were found in the gyttja and gyttja clay soils. The mean contents of $\mathrm{Mn}$ were highest in the anaerobic subsoil samples.

The $\mathrm{pH}$-values in the subsurface soil samples were the lower the more the soil included sulphur, aluminium or iron. Aluninium and iron were in positive correlation with each other. The more sulphur in the soil the higher the conductivity. The pH-value of soil decreased with increasing conductivity.
\end{abstract}

Rikkipitoiset maat kuuluvat Suomessa Litorinamerivaiheen aikana tai sen jälkeen suolaiseen veteen laskeutuneisiin sedimenttimaihin. Litorinamerivaihe alkoi täällä noin 5000 vuotta e.Kr. ja meren korkein rantaviiva oli silloin Etelä-Pohjanmaalla $90-100 \mathrm{~m}$ meren nykyisen pinnan yläpuolella (Окко 1967). Tuolla kaudella syntyneet rikkipitoiset maat tunnetaan happamina sulfaattimaina (Frosterus 1914). Niitä tavataan eri puolilla maapalloa lähinnä merien rannikoilla (KAWALEC 1973). Rikki on joutunut näihin sedimentteihin meriveden sulfaateista ja orgaanisen, merenpohjaan laskeutuneen kasvi- ja eläinjätteen valkuaisaineesta. Suurin osa rikistä esiintyy veden alaisissa sedimenteissä rautasulfideina, joiksi rikki on alkulähteistään pelkistynyt tiettyjen rikkibakteerien vaikutuksesta (RICKARD 1972). Maan joutuessa ilman kanssa kosketuksiin, kuten maan kohoamisen johdosta Suomessa on tapahtunut, ha- 
pettuu sulfidi sulfaatiksi, mihin näiden maiden nimikin perustuu. Tätä maannostyyppiä on nimitetty myös alunamaaksi kuivina kausina kapillaarisesti maan pintaan kulkeutuvien ja siinä kiteytyvien alunatyyppisten suolojen vuoksi (AARNIO 1924).

Sulfaattimaille on ominaista paitsi runsas rikin määrä, alhainen pH (BRINKMAN et al. 1973, KEvIE 1973), suuri elektrolyyttien määrä, johon korkea johtoluku perustuu (PURoKoski 1958 ja 1959), sekä myös suhteellisen korkea orgaanisen aineksen määrä.

Suomessa tehdyssä rikkipitoisten maitten inventoinnissa löydettiin näitä maita meiltä noin 51000 ha (PURokoski 1959). Yli puolet tästä alasta sijaitsee Etelä-Pohjanmaalla ja haitallisesti rikkipitoiset maat suurelta osalta Kyrönjoen varsilla. AARNio (1927) on todennut Etelä-Pohjanmaan agrogeologista karttaa koskevassa julkaisussaan tasangoilla esiintyvien litorinasavien sisältävän runsaasti sekä rikkiä, sulfaattien ja sulfidien muodossa, että rautaa. Korkman (1973) on laskenut LAAKSOSEN (1970) tutkimusten pohjalta Kyrönjoen vesistöalueelta uuttuvan rikkiä $33 \mathrm{~kg} / \mathrm{ha}$ vuodessa.

Vesihallituksen asettaman työryhmän toimesta valmistui v. 1973 selvitys Kyrönjoen ja sen edustan merialueen kalakuolemien syistä (ANoN. 1973). Selvitystä varten Maantutkimuslaitos inventoi Kyrönjoen vesistöalueen rikkipitoiset maa-alueet ja tutki niiden maaperän kemiallisia ominaisuuksia. Tässä julkaisussa käsitellään edellä mainitun maaperäaineiston tuloksia.

\section{Aineisto ja analyysimenetelmät}

Kyrönjoen valuma-alueelta pyrittiin kartoittamaan vähintään 100 ha:n suuruiset yhtenäiset rikkipitoisten viljelymaiden alueet. Tuloksen varmentamiseksi otettiin maanäytteitä 221 pisteestä, yhteensä noin $660 \mathrm{kpl}$. Näytteet otettiin kustakin pisteestä kolmesta kerroksesta: muokkauskerroksesta $0-20$ cm:n (muokkauskerros), $50-70 \mathrm{~cm}: n$ (keskikerros) sekä pohjaveden pinnan alapuolelta 150 ja $400 \mathrm{~cm}: n$ väliltä (pohjamaa), niin että $97 \mathrm{kpl}$ oli $100-200$ cm:n, $95 \mathrm{kpl} 200-300 \mathrm{~cm}: \mathrm{n}$ ja $20 \mathrm{kpl}$ yli $300 \mathrm{~cm}: n$ syvyydestä. Näytteistä oli hietoja 137, hiesuja 188, hieta-, hiesu- ja aitosavia 94, liejusavia ja liejuja 81 , saraturpeita 57 sekä multamaita $104 \mathrm{kpl}$.

Rikkipitoisiksi maiksi inventoitiin alueet, joiden hapettuneen kerroksen (50-70 cm:n syvyys) maanäytteissä todettiin alhainen $\mathrm{pH}$-arvo ja korkea rikkipitoisuus. Tähän ryhmään luettiin maat, joiden $\mathrm{pH}$-arvo oli alle $\mathrm{pH}$ 5.0 ja (tai) jotka sisälsivät sulfaattirikkiä vähintään $100 \mathrm{mg} /$ litra maata eli $0.01 \%$, kun maan tilavuuspainon oletetaan olevan 1. Rikkipitoisten maiden varmana tunnusmerkkinä pidettiin maastotutkimuksissa myös pohjaveden pinnan alapuolelta, anaerobisesta tilasta otetun maan tummanharmaata tai mustaa väriä, mikä johtuu rautasulfidista.

Maanäytteet kuivattiin $25-30^{\circ}$ C:ssa, jauhettiin $2 \mathrm{~mm}: n$ seulan läpi ja analysoitiin 5-7 kk:n päästä näytteiden otosta. Alkuainepitoisuudet on ilmaistu kuivatusta ja jauhetusta maasta saatua tilavuusyksikköä kohti.

Sulfaattirikki määritettiin atomiabsorptiospektrofotometrillä maan happamasta ammoniumasetaattiuutteesta, joka oli $0.5 \mathrm{~N}$ ammoniumasetaatin ja $0.5 \mathrm{~N}$ etikkahapon suhteen, $\mathrm{pH}: \mathrm{n}$ ollessa 4.65 ja uuttosuhteen 1:10 (VuORINEN 
ja Mäкıтı 1955). Maanäytteistä määritettiin lisäksi: $\mathrm{pH}$, johtoluku, Ca, K, $\mathrm{Mg}, \mathrm{Fe}, \mathrm{Al}$ ja $\mathrm{Mn}$. Johtoluku ja $\mathrm{pH}$ mitattiin maa-vesisuspensiosta (til.suhde 1:2.5). Alkuaineista $\mathrm{Ca}$ ja $\mathrm{K}$ määritettiin liekkifotometrillä ja $\mathrm{Mg}, \mathrm{Fe}, \mathrm{Al}$ ja Mn atomiabsorptiospektrofotometrillä happaman ammoniumasetaattin uutteesta. Ilmoitettu johtoluku $(\mathrm{JL})=$ ominaisjohtokyky $(\mathrm{mho} / \mathrm{cm}) \times 10^{4}$. Orgaaninen hiili määritettiin dikromaattimärkäpoltolla, josta saatu hiiliarvo kerrottiin luvulla 1.73 maalajiluokituksessa käytettäviin humusarvoihin pääsemiseksi.

Multamaiksi on luettu ne pintamaanäytteet, joiden humuspitoisuus on $15-39 \%$. Muokkauskerroksen alapuolelta otetut savinäytteet on luokiteltu liejusaviksi, jos ne ovat sisältäneet humusta 3.0-5.9\%, ja liejuiksi, jos humusta on ollut vähintään $6.0 \%$ mutta alle $40 \%$, joka on turpeiden humuspitoisuuden alaraja. Maanäytteistä tehtiin 106 mekaanista analyysiä oikean maalajinimityksen varmistamiseksi käyttäen $\mathrm{H}_{2} \mathrm{O}_{2}-\mathrm{HCl}-\mathrm{Na}_{4} \mathrm{P}_{2} \mathrm{O}_{7}$-esikäsittelyä ja ns. pipettimenetelmää.

\section{Sulfaattimaiden pinta-alat}

Tutkimuksessa inventoitiin sulfaattimaiksi kaikkiaan 26400 ha viljelymaata (taulukko 1), mikä on $5.4 \%$ Kyrönjoen valuma-alueen pinta-alasta, $4900 \mathrm{~km}^{2}$ :stä ja $19.0 \%$ alueen viljellystä pinta-alasta. Jos pienialaiset rikkonaisetkin peltoalueet otettaisiin lukuun, kasvaisi ala arvion mukaan viidenneksellä. Näiden alueiden ulkopuolelle jäävät vielä suot, joista laajimmat varsinkin Kyrönjoen suupuolella ovat syntyneet litorinamaalle, sekä lisäksi metsät, joista myös osa sijaitsee tällä maatyypillä. Koko litorinamaa-alaksi voidaan Kyrönjoen valuma-alueella hyvällä syyllä arvioida $35000-40000$ ha.

Suurin osa todetuista sulfaattimaista sijaitsee Kyrönjoen alajuoksun laajoilla tasankomailla korkeintaan $\mathbf{5 0}$ metriä merenpinnan tasoa ylempänä (taulukko 1 ja kuva 1), toisin sanoen Ilmajoen kirkonkylästä jokisuulle päin. Sulfaattimaaalasta saattuu $80 \% 15$ ja 45 metrin välille merenpinnan tasosta. Myös 50 metrin tason yläpuolelta, aina 90 metristä löytyy vähäisiä alueita, joita edustaa lasketun Haasjärven peltokuivio Peräseinäjoen suunnalla.

\section{Kemialliset ominaisuudet}

Maan pH ja johtoluku. Viljelytoimenpiteiden vaikutuksessa olleen muokkauskerroksenkin $\mathrm{pH}$-arvot osoittautuivat yleisesti ottaen suhteellisen alhaisiksi: kivennäismaat keskimäärin $\mathrm{pH}$ 5.4, multamaat 5.2 ja turvemaat 5.0 (taulukko 2). Kerroksen $\mathbf{5 0 - 7 0} \mathrm{cm}$ keskimääräiset $\mathrm{pH}$-arvot olivat huomattavan alhaisia, liejusavella ja liejulla jopa alle $\mathrm{pH}$ 4. Aineistossa todettiin $\mathrm{pH} 3.0: n$ arvoisia lukemia myös hieta- ja hiesumaissa. Tämän kerroksen keskiarvot olivat joka maalajiryhmässä muokkauskerroksen ja pohjamaan vastaavia arvoja alhaisempia. Pohjamaan liejujen ja etenkin liejusavien keskimääräiset $\mathrm{pH}$-arvot 4.5 ja 5.8 olivat huomattavasti keskikerroksen vastaavia, $\mathrm{pH} 3.9$ ja 3.9 , arvoja korkeammat.

Pintamaiden johtoluku oli keskimäärin alhaisin 1.4, hietaryhmässä ja korkein saraturveryhmässä 2.2 , muiden maalajiryhmien sijoittuessa näiden väliin. Keskikerroksen keskimääräiset maalajittaiset johtoluvut olivat hiedoilla, 


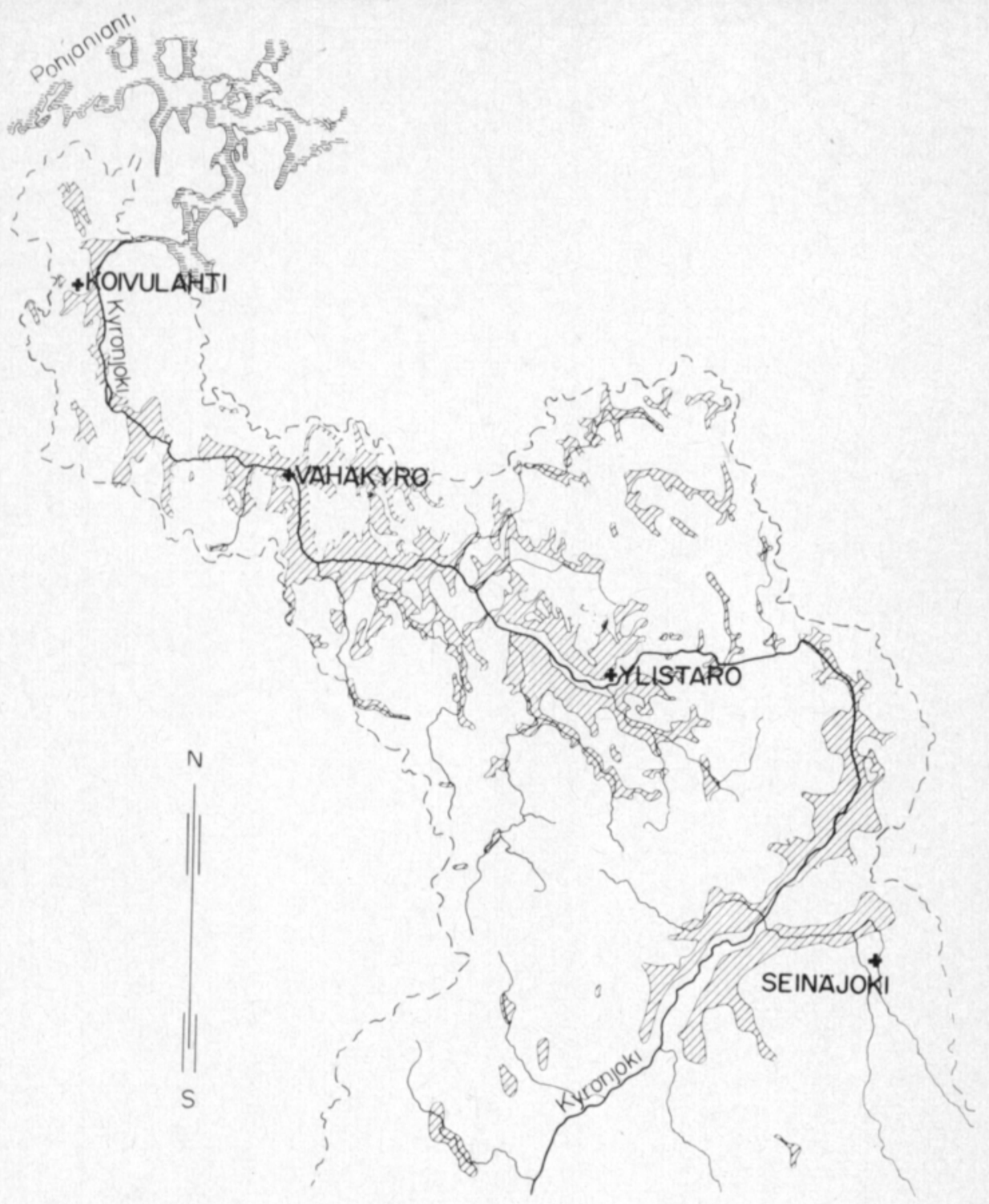

Kuva 1. Kyrönjoen valuma-alueen laajimmat sulfaattimaa-alueet.

Fig. 1. The areas of sulphate soils in the drainage basin of river Kyrönjoki.

hiesuilla, savilla ja saraturpeilla samaa luokkaa, mutta liejusavella (3.4) ja liejulla (11.0) jo huomattavasti korkeammat. Tämän kerroksen yksittäisten lukujen vaihtelu maalajiryhmän sisällä on selvästi pintamaissa todettua laajempaa. Korkein johtolukuarvo 18.3 mitattiin liejulla. Syvimmän kerroksen näytteiden johtolukujen keskiarvot ylittivät hieta-, hiesu-, savi- ja liejusaviryhmissä selvästi jankon vastaavat luvut ja kaikista ryhmistä löytyi myös suhteellisen korkeita yksittäisiä arvoja.

Rikki. Näytekerroksittain rikkipitoisuuksia tarkasteltaessa havaitaan, että maalajiryhmien sulfaattirikin keskimääräiset pitoisuudet olivat turvemaita lukuunottamatta alhaisimmat muokkauskerroksessa ja hiesua lukuunotta- 
Taulukko 1. Rikkipitoisten viljelymaiden alat ja sijainti karttalehdittäin.

Table 1. The areas of sulphate soils and their location above the sea level on various Basic Maps.

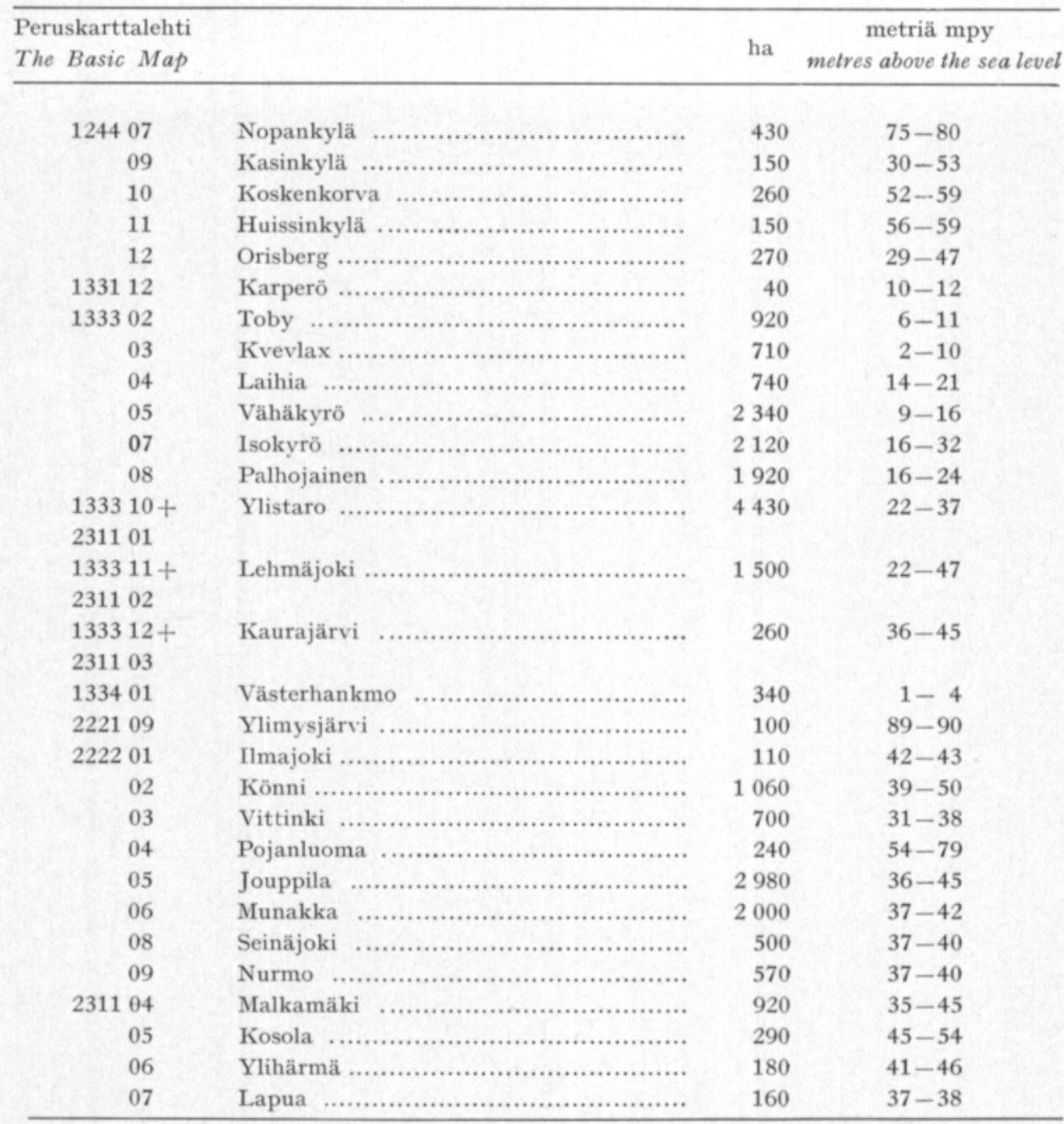

Yhteensä - Total

26390

matta korkeimmat keskikerroksessa (taulukko 2). Muokkauskerroksen viiden maalajiryhmän rikin pitoisuuden keskiarvot rajoittuivat 33 ja 56 mg:n välille. Sensijaan keskikerroksessa maalajien väliset erot rikin pitoisuudessa olivat toista luokkaa. Kun saraturpeissa oli rikkiä keskimäärin vain $34 \mathrm{mg}$, oli liejuissa peräti $1379 \mathrm{mg}$. Myös liejusavien $(26 \mathrm{kpl}$ ) keskiarvo $422 \mathrm{mg}$ viittaa erittäin selviin sulfaattimaihin.

Pohjamaiden keskimääräiset sulfaattirikin määrät jäävät hiesuryhmää lukuunottamatta keskikerroksen vastaavien arvojen alapuolelle, ja suhteellinen ero oli suurin liejuryhmän keskiarvojen 721 ja $1379 \mathrm{mg} / \mathrm{l}$ välillä. Näytteiden rikin pitoisuuksien hajonta oli maalajiryhmienkin sisällä varsin suuri. Pintamaihin sisältyi jokaisessa maalajiryhmässä näytteitä, joiden rikin pitoisuus todettiin käytetyllä menetelmällä nollaksi, sensijaan kaikissa keskikerrok- 


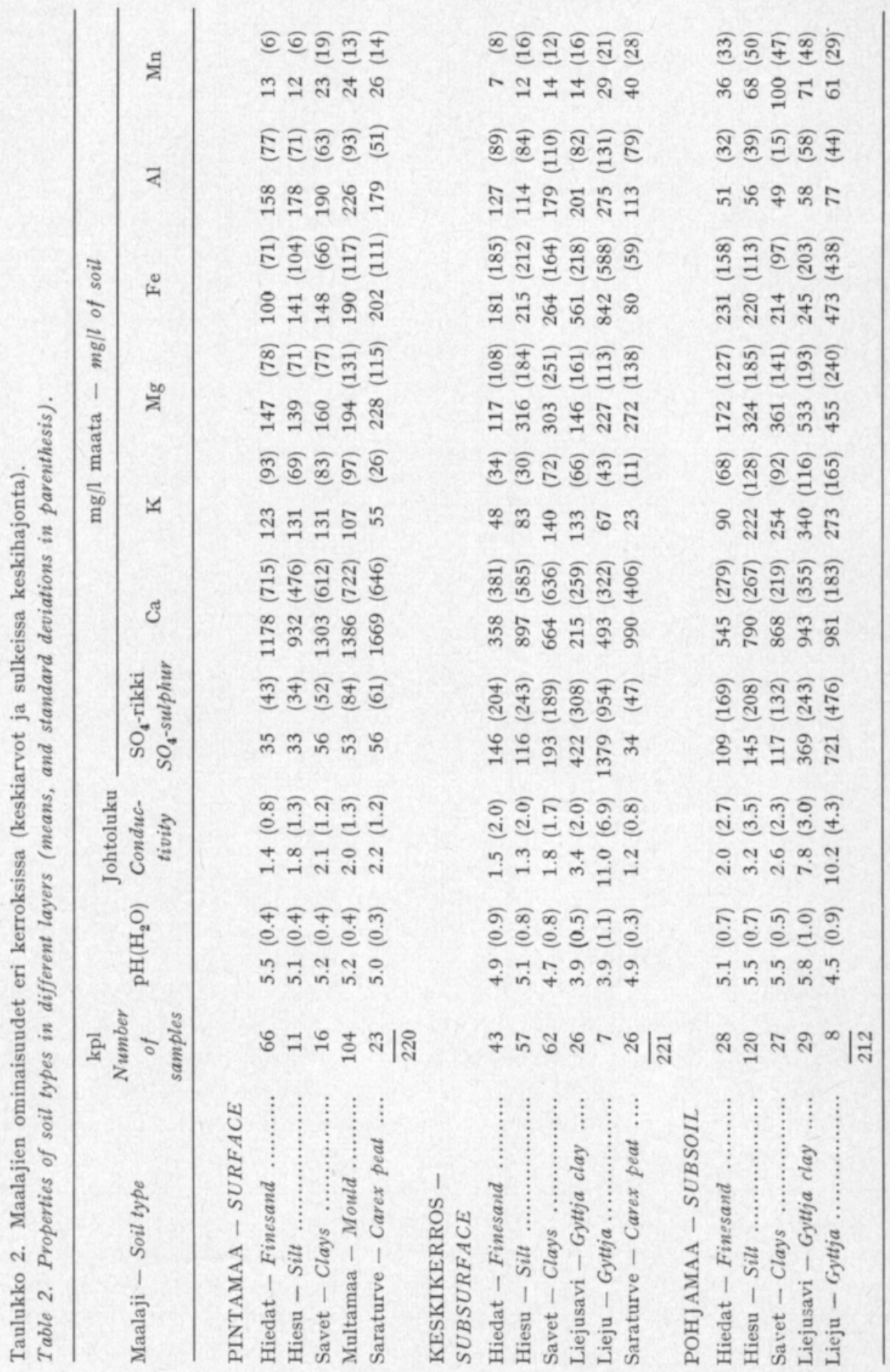


sen ja pohjamaan liejusavissa ja liejuissa todettiin rikkiä vähintään $20 \mathrm{mg} / \mathrm{l}$. Pintamaiden korkein arvo $490 \mathrm{mg}$ oli multamaassa, keskikerroksen $2450 \mathrm{mg}$ ja pohjamaiden $1500 \mathrm{mg}$ liejuissa. Yli $1000 \mathrm{mg}$ rikkiä oli kuudessa keskikerroksen maanäytteessä, joista viisi oli liejua ja yksi liejusavi. Näistä näytteistä viisi oli otettu korkeustasolta 36-47 metriä mpy. ja yksi, aineiston korkeinta arvoa edustava näyte, 90 metrin tasolta Haasjärven peltokuiviosta.

Kivennäismaiden näytteet ryhmiteltiin taulukossa 3 näytteenottokohdan korkeuden merenpinnasta mukaan, jolloin todettiin että pintamaan sulfaattirikkipitoisuuksissa ei ollut kovin suuria eroja korkeustason suhteen. Sensijaan keskikerroksen näytteiden keskimääräinen rikkipitoisuus oli korkeustasolla $0-39 \mathrm{~m}$ noin $340 \mathrm{mg}$, korkeustasolla $40-59 \mathrm{~m}$ noin $134 \mathrm{mg}$ sekä korkeustasoilla $60-79 \mathrm{~m}$ ja yli $80 \mathrm{~m}$ enää 40 ja $31 \mathrm{mg}$. Syvimmän näyteryhmän keskimääräiset pitoisuudet olivat korkeustasolla $40-59 \mathrm{~m}$ ja $60-79 \mathrm{~m}$ selvästi suuremmat kuin keskikerroksen vastaavat pitoisuudet, mutta yli $80 \mathrm{~m}$ : $\mathrm{n}$ tasolla pitoisuuseroja ei ollut minkään kerrosten välillä.

Taulukko 3. Keskimääräiset sulfaattirikkipitoisuudet kivennäismaissa eri korkeustasoilla Table 3. The average contents of sulphate-S in mineral soils on the various high levels.

\begin{tabular}{|c|c|c|c|c|c|c|}
\hline \multirow{2}{*}{$\begin{array}{c}\text { Näytepaikan korkeus } \\
\text { merenpinnasta } \\
\text { Metres above the } \\
\text { sea level }\end{array}$} & \multicolumn{2}{|c|}{$\begin{array}{c}\text { Syvyys - Depth } \\
0-20 \mathrm{~cm}\end{array}$} & \multicolumn{2}{|c|}{$\begin{array}{c}\text { Syvyys - Depth } \\
50-70 \mathrm{~cm}\end{array}$} & \multicolumn{2}{|c|}{$\begin{array}{c}\text { Syvyys }- \text { Depth } \\
>100 \mathrm{~cm}\end{array}$} \\
\hline & $\begin{array}{c}\text { kpl } \\
\text { number }\end{array}$ & $\begin{array}{c}\mathrm{SO}_{4}-\mathrm{S} \\
m g / l\end{array}$ & $\begin{array}{c}\text { kpl } \\
\text { number }\end{array}$ & $\begin{array}{c}\mathrm{SO}_{4}-\mathrm{S} \\
m g / l\end{array}$ & $\begin{array}{c}\text { kpl } \\
\text { number }\end{array}$ & $\begin{array}{l}\mathrm{SO}_{4}-\mathrm{S} \\
m g / l\end{array}$ \\
\hline $0-19 \mathrm{~m} \quad \ldots . . . .$. & 16 & 48 & 35 & 339 & 33 & 275 \\
\hline $20-39 \mathrm{~m} \ldots \ldots \ldots \ldots \ldots \ldots \ldots \ldots \ldots \ldots$ & 13 & 48 & 49 & 343 & 48 & 208 \\
\hline $40-59 \mathrm{~m}$ & 20 & 44 & 37 & 134 & 42 & 281 \\
\hline 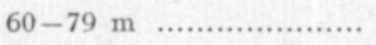 & 10 & 24 & 12 & 40 & 11 & 149 \\
\hline 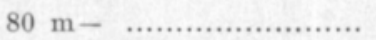 & 34 & 31 & 55 & 31 & 70 & 30 \\
\hline
\end{tabular}

Rauta. Pintamaiden helppoliukoinen rauta lisääntyi hietamaista hiesu- ja savimaihin päin, ja näistä edelleen eloperäisiin maihin päin ollen saraturpeilla keskimäärin kaksinkertainen $(202 \mathrm{mg} / \mathrm{l})$ hietamaihin verrattuna. Keskikerroksen saraturpeen arvo oli vain $\mathbf{8 0}$, mutta muiden maalajiryhmien keskiarvot pintamaiden arvoja suuremmat. Tämän kerroksen Fe-arvo oli erityisen korkea liejusavilla (561 mg) sekä liejuilla $(842 \mathrm{mg})$. Yksittäisen liejunäytteen huippuarvo nousi jopa $1652 \mathrm{mg} \mathrm{Fe} / \mathrm{l}$ maata. Pohjamaiden Fe-arvoissa ei maalajien välillä yleensä ollut merkittäviä eroja lukuunottamatta liejun muihin nähden kaksinkertaista arvoa (473 mg).

Alumiini. Pintamaan alumiinin pitoisuudet olivat eri maalajeilla saraturvetta lukuunottamatta hiukan raudan pitoisuuksia suurempia. Sensijaan keskikerroksessa tilanne oli juuri päinvastainen, vain saraturve sisälsi rautaa alumiinia enemmän. Liejusavessa raudan määrä oli 2.5- ja liejussa 3-kertainen alumiinin määrään verrattuna. Pohjamaassa tilanne on muuttunut vielä jyrkemmäksi, niin että kaikissa maalajiryhmissä alumiinin määrä edustaa enintään neljättä osaa raudan määrästä. 
Mangaani. Muokkauskerroksen ja 50-70 cm:n kerroksen maalajittaiset Mn-keskiarvot olivat keskenään jotakuinkin samaa luokkaa, mutta syvimmän tutkitun kerroksen selvästi näitä korkeampia. Eloperäisten maiden, kuten muokkauskerroksen turpeiden ja multamaiden sekä $50-70 \mathrm{~cm}: n$ kerroksen turpeiden ja liejujen mangaanin pitoisuudet ylittivät keskimäärin vastaavien kerrosten kivennäismaiden pitoisuudet. Kaikissa maalajiryhmissä esiintyi pitoisuuksissa laajaa hajontaa. Korkeimmat arvot muokkaus- ja keskikerroksessa jäivät alle $100 \mathrm{mg}: \mathrm{n}$, mutta nousivat pohjamaassa kaikissa maalajiryhmissä yli sen, suurimman arvon ollessa hiesulla $432 \mathrm{mg} \mathrm{Mn} / 1 \mathrm{maata}$. Pohjamaan 27 savinäytteen keskiarvokin ylti 100 mg:aan.

Paljon rikkiä sisältävät maat sisälsivät myös mangaania enemmän kaikissa kerroksissa, kuten seuraavasta asetelmasta ilmenee:

\begin{tabular}{llcc} 
& & \multicolumn{2}{c}{ Mn mg/l maata } \\
\cline { 3 - 3 } & & 13 & 20 \\
\cline { 3 - 3 } Pintamaa & kivennäismaat & 23 & 38 \\
& turpeet & 9 & 14 \\
Keskikerros & kivennäismaat & 58 & 94 \\
Pohjamaa & kivennäismaat & & $\mathrm{S}>100 \mathrm{mg} / 1$ \\
& &
\end{tabular}

Kalsium, kalium ja magnesium. Kalsiumin, kaliumin ja magnesiumin keskimääräiset pitoisuudet vaihtelivat muokkauskerroksessa maalajien välillä melko vähän ja odotettuun suuntaan edustaen viljelyä ajatellen tyydyttävää ravinnetilaa. Keskikerroksen liukoiset Ca-, K- ja Mg-määrät olivat maalajiryhmittäin keskimäärin vähäisemmät kuin pohjamaassa, etenkin liejusavi- ja liejuryhmissä erot olivat huomattavat. Varsinkin pohjamaan magnesiumpitoisuuksia voidaan pitää yllättävän korkeina.

\section{Kemiallisten ominaisuuksien vuorovaikutukset}

Keskikerroksen aineistosta lasketut suoraviivaiset riippuvuussuhteet (taulukko 4) osoittavat, että maan vesi-pH oli sitä alhaisempi mitä enemmän maa sisälsi sulfaattirikkiä, helppoliukoista rautaa tai alumiinia, jotka taas olivat positiivisessa vuorosuhteessa keskenään. Maalajiryhmittäin asiaa tarkasteltaessa rikin ja alumiinin sekä raudan ja alumiinin välillä ei tilastollisesti merkitsevää vuorosuhdetta kuitenkaan esiintynyt liejusaviryhmässä. Mitä korkeampi oli maasta mitattu johtoluku sitä alhaisempi oli maan $\mathrm{pH}$-arvo. Edellä todetun johdonmukaisena seurauksena havaitaan sekä rikin että raudan ja alumiinin määrän olevan erittäin merkitsevällä tilastollisella varmuudella kaikissa maalajiryhmissä positiivisessa vuorosuhteessa johtolukuun jälleen liejusaviryhmää lukuunottamatta.

Taulukosta 5 havaitaan, että hieta- ja hiesuryhmissä maan sulfaattirikin pitoisuus näyttää selvittävän suuremman osan maan $\mathrm{pH}$ :n vaihteluista kuin rauta- tai alumiinipitoisuus. Savi- ja liejuryhmissä sitä vastoin Fe-pitoisuuden selvitys- $\%$ on suurempi kuin rikin tai alumiinin, ja alumiinikin näyttää selvittävän savi- ja liejuryhmissä enemmän $\mathrm{pH}: n$ vaihtelusta kuin rikki. 
Taulukko 4. Korrelaatiokertoimet $\mathrm{pH}: \mathrm{n}, \mathrm{SO}_{4}$-rikin, raudan, alumiinin ja johtoluvun välillă keskikerroksen eri maalajiryhmissä.

Table 4. The correlation coefficients for the relation between $\mathrm{pH}\left(\mathrm{H}_{2} \mathrm{O}\right), \mathrm{SO}_{4}$-sulphu, iron, aluminium and conductivity of different soil types in subsurface layer.

\begin{tabular}{|c|c|c|c|c|c|c|}
\hline & $\begin{array}{c}\text { Hieno hieta } \\
\text { Finer fine sand } \\
26 \mathrm{kpl} \\
\text { samples }\end{array}$ & $\begin{array}{l}\text { Hiesu } \\
\text { Silt } \\
57 \mathrm{kpl} \\
\text { samples }\end{array}$ & $\begin{array}{l}\text { Savet } \\
\text { Clays } \\
62 \mathrm{kpl} \\
\text { samples }\end{array}$ & $\begin{array}{c}\text { Liejusavi } \\
\text { Gyttja clay } \\
26 \mathrm{kpl} \\
\text { samples }\end{array}$ & $\begin{array}{l}\text { Lieju } \\
\text { Gyttia } \\
7 \mathrm{kpl} \\
\text { samples }\end{array}$ & $\begin{array}{c}\text { Kaikki } \\
\text { All material } \\
194 \mathrm{kpl} \\
\text { samples }\end{array}$ \\
\hline r $\mathrm{S} / \mathrm{pH} \ldots \ldots \ldots \ldots \ldots$ & $-0.90 * * *$ & $-0.75^{* * *}$ & $-0.77 * * *$ & $-0.55^{* *}$ & $-0.96^{* * *}$ & $-0.68 * * *$ \\
\hline r S/Fe ................ & $+0.92 * * *$ & $+0.87^{* * *}$ & $+0.68^{* * *}$ & +0.35 & $+0.98 * * *$ & $+0.83^{* * *}$ \\
\hline r S/Al .................. & $+0.65^{* * *}$ & $+0.61 * * *$ & $+0.68 * * *$ & +0.12 & $+0.82^{*}$ & $+0.55^{* * *}$ \\
\hline $\begin{array}{l}\text { r S/johtoluku ........ } \\
\text { S/conductivity }\end{array}$ & $+0.86 * * *$ & $+0.97 * * *$ & $+0.77 * * *$ & $+0.78^{* * *}$ & $+0.99 * * *$ & $+0.94^{* * *}$ \\
\hline r $\mathrm{Fe} / \mathrm{pH} \ldots \ldots \ldots \ldots \ldots$ & $-0.84 * * *$ & $-0.73 * * *$ & $-0.82 * * *$ & $-0.58^{* *}$ & $-0.90^{* * *}$ & $-0.76^{* * *}$ \\
\hline r $\mathrm{Fe} / \mathrm{Al} \ldots \ldots \ldots \ldots \ldots$ & $+0.61 * * *$ & $+0.60 * * *$ & $+0.81 * * *$ & +0.30 & $+0.76^{*}$ & $+0.62 * * *$ \\
\hline $\begin{array}{l}\text { r Fe/johtoluku ...... } \\
\text { Fe/conductivity }\end{array}$ & $+0.73^{* * *}$ & $+0.85^{* * *}$ & $+0.67^{* * *}$ & +0.11 & $+0.98^{* * *}$ & $+0.81 * * *$ \\
\hline r $\mathrm{Al} / \mathrm{pH} \ldots \ldots \ldots \ldots \ldots$ & $-0.73 * * *$ & $-0.84 * * *$ & $-0.82^{* * *}$ & -0.15 & -0.79 & $-0.72 * * *$ \\
\hline $\begin{array}{l}\text { r Al/johtoluku ........ } \\
\text { Al/conductivity }\end{array}$ & $+0.62^{* * *}$ & $+0.61 * * *$ & $+0.54 * * *$ & -0.02 & $+0.76^{*}$ & $+0.51 * * *$ \\
\hline $\begin{array}{l}\mathrm{r} \mathrm{pH} / \text { johtoluku } . . . . \\
\text { pH/conductivity }\end{array}$ & $-0.79 * * *$ & $-0.75^{* * *}$ & $-0.61 * * *$ & $-0.48^{* *}$ & $-0.96 * * *$ & $-0.66^{* * *}$ \\
\hline
\end{tabular}

Taulukko 5. Keskikerroksen näytteiden pH-arvojen selvittyvyysprosentit S-, Fe- ja Alpitoisuuksien perusteella.

Table 5. The coefficient of determination of $\mathrm{pH}$ on contents of $\mathrm{S}, \mathrm{Fe}$ and $\mathrm{Al}$ (subsurface layer).

\begin{tabular}{|c|c|c|c|}
\hline Maalaji - Soil type & $\begin{array}{l}\text { coefficient } \\
\mathrm{S}\end{array}$ & $\begin{array}{l}\text { Selvitys- } \% \\
\text { of determination as per } \\
\mathrm{Fe}\end{array}$ & $\begin{array}{c}\text { cents } \\
\mathrm{Al}\end{array}$ \\
\hline Hiedat - Finesand .................. & $88.3 \%$ & $82.3 \%$ & $74.5 \%$ \\
\hline Hiesu - Silt .................................. & 86.3 & 66.0 & 74.4 \\
\hline Savet - Clays . .................................. & 69.4 & 74.6 & 72.3 \\
\hline Liejusavi - Gyttja clay ........................ & 35.1 & 56.4 & 33.8 \\
\hline Lieju - Gyttja .................................. & 68.7 & 86.7 & 80.7 \\
\hline
\end{tabular}

\section{Tulosten tarkastelu}

Suomessa todetuista sulfaattimaaesiintymistä sijaitsee suhteellisen suuri osuus Etelä-Pohjanmaan alueella. Purokosken (1959) suorittamassa rikkipitoisten maiden inventoinnissa kartoitettiin Suomesta n. 38000 ha:n ala, josta puolet eli n. 19000 ha sijaitsi juuri Kyrön-, Närpiön-, Laihian-, Vöyrin-, Munsalan- ja Lapuanjokien valuma alueilla. Kun esillä olevassa tutkimuksessa todettiin pelkästään Kyrönjoen valuma-alueelta 26000 ha rikkipitoisia viljelymaita, on näiden maiden osuus Etelä-Pohjanmaalla selvästi suurempi kuin mitä tutkimuksilla tähän mennessä on voitu osoittaa. 
Tutkimuksessa analysoitu sulfaattirikki edustaa vain osaa maanäytteiden sisältämästä rikistä, mutta sulfaattimuodossa olevan rikin tiedetään kuitenkin muodostavan pääosan, noin $90 \%$, luonnossa aerobisessa tilassa esiintyvän maan epäorgaanisen rikin kokonaismäärästä, kuten PUROKOSKI (1956) on osoittanut. Pohjamaasta anaerobisesta tilasta otetuissa näytteissä epäorgaaninen rikki on alunperin esiintynyt suurelta osin sulfidimuodossa, mikä maanäytteiden kuivuessa hapettuu mahdollisten alkuaine- ja sulfiittirikkivälimuotojen kautta loppujen lopuksi sulfaattirikiksi (WikLAnder, Hallgren ja Jansson 1950, PURoKoski 1958, Rasmussen 1961).

Aineiston muokkauskerroksen näytteiden $\mathrm{SO}_{4}$-rikin pitoisuus on selvästi korkeampi kuin suomalaisissa viljelymaissa yleisesti. Korkman (1973) sai samalla uuttonesteellä 22 hiekka- ja hietamaanäytteen rikin keskiarvoksi 7 mg, 15 savimaanäytteen $8 \mathrm{mg}$ ja 14 turve- ja multamaanäytteen niin ikään $8 \mathrm{mg} \mathrm{S} / 1$ maata, kun tässä aineistossa vastaavien maalajiryhmien keskiarvot olivat 35,65 ja $54 \mathrm{mg} / \mathrm{l}$. PUROKosken (1959) inventoimien rikkipitoisten alueiden maat Etelä-Pohjanmaalla sisälsivät $40-60 \mathrm{~cm}$ :n kerroksessa rikkiä aineiston pääosassa $500-2500 \mathrm{mg} / \mathrm{l}$ maata, jolle tasolle tässä aineistossa vastaavan kerroksen näytteistä ylti vain 42 sulfaattimaa-alueita edustavista 92 näytteestä.

Eri korkeustasoilta merenpinnasta otettujen näytteiden keskimääräiset sulfaattirikkipitoisuudet viittasivat siihen, että sulfaattirikkiä on aikaa myöten huuhtoutunut pintamaasta pois, ja että yli $80 \mathrm{~m}: \mathrm{n}$ tason näytteissä sitä ei normaalia runsaammin ole ilmeisesti ollutkaan. Eniten rikkiä sisältäneet maat sijoittuivat 60 metrin korkeustason alapuolelle, missä laajimmat rikkipitoisten maiden esiintymätkin sijaitsevat.

Keskikerroksen erittäin alhainen $\mathrm{pH}$-arvo ilmentää aineistolle tyypillisten sulfaattimaiden ominaisuutta. Tässä kerroksessa epäorgaaninen rikki on pääosaltaan hapettunut sulfaatiksi. Sulfaattimaan $\mathrm{pH}$ laskee maan kuivattamisen jälkeen selvästi alle pH 5:n, usein jopa lähelle pH 3:a (KIvinen 1938). Näin alhainen $\mathrm{pH}$-arvo johtuu lähinnä hapetustapahtuman yhteydessä syntyvästä vapaasta rikkihaposta.

Monet esillä olevan tutkimuksen sulfidimaatyyppisistä, pohjaveden pinnan alapuolelta otetuista näytteistä antoivat kuukauden kuivatuksen jälkeen jopa $\mathrm{pH}$ 7-luokkaa olevia arvoja, vaikka niiden rikkipitoisuus oli suhteellisen korkea. Tästä on HANNERZ (1934) todennut, että anaerobisessa tilassa olleen maan rautasulfidin hapettuminen rikkihapoksi tapahtuu vähitellen, ja että maanäytteiden nopeasti kuivuessa, jolloin kosteana mustan maan väri muuttuu vaalean harmaaksi, edellyttää vain yhtälön $4 \mathrm{FeS}+3 \mathrm{O}_{2}+6 \mathrm{H}_{2} \mathrm{O}=4 \mathrm{Fe}(\mathrm{OH})_{3}$ $+4 \mathrm{~S}$ mukaista tapahtumaa. Maanäytteen kosteana pitäminen aerobisissa oloissa vasta saa hydrolyysi-ilmiön aikaan, ja täydellinen hapettuminen rikkihapoksi saakka pääsee tapahtumaan, jolloin mitattava $\mathrm{pH}$ vasta kuvaa sulfaattimaan pH:ta, kuten Kivinen (1944) on kokeissaan todennut. Sulfidin hapettumisen jälkeenkään ei maan $\mathrm{pH}$ voi alentua kovin paljon silloin, kun maa sisältää käsiteltävän aineiston pohjamaakerroksessa todetussa määrin puskuroivasti vaikuttavia kationeja kuten magnesiumia, kalsiumia ja kaliumia.

Maan elektrolyyttipitoisuutta ilmentävä johtoluku on sulfaattimaiden tunnistamisessa ehkä pH-arvoakin parempi suure, niinkuin taulukon 4 rikin ja $\mathrm{pH}: \mathrm{n}$ sekä rikin ja johtoluvun välisistä korrelaatiokertoimista voidaan päätellä. 
Johtoluku ilmaisee sekä kationien että anionien yhteismäärän, joita molempia suolamaihin kuuluvat sulfaattimaat sisältävät runsaasti. Koska meillä Suomessa ei käytännöllisesti katsoen ole alkaalisuolamaita, voidaan kaikki keskikerroksen poikkeuksellisen korkean johtoluvun omaavat maat lukea happa mien sulfaattimaiden ryhmään.

Tutkitut maat ovat yleisesti sisältäneet runsaasti liukoista rautaa myös muokkauskerroksessa. Saadut arvot ovat kaksin-kolminkertaisia SILLANPÄÄn ja LAKASEN (1966) eri puolilta Suomea otettujen lähes 500 maanäytteen vastaaviin maalajittaisiin keskiarvoihin verrattuina. Molemmissa aineistoissa todettiin eloperäisten maiden Fe-pitoisuudet kivennäismaiden pitoisuuksia korkeammiksi.

Alumiinin määrityksiä on tehty suomalaisista maista tässä käytetyllä uuttomenetelmällä hyvin vähän, mutta MäкıтıEn (1968) pintamaanäytteistä (30 kpl) saama keskiarvo 1.75 mekv Al/100 g maata, mikä vastaa $\mathrm{n} .158 \mathrm{mg}$ $\mathrm{Al} / 1$ maata, jää alle tämän aineiston pintamaiden keskiarvoa $196 \mathrm{mg}$.

Paitsi rautaa ja alumiinia totesi Pohjois-Ruotsin alunamaita jo 1920luvulla tutkinut HANNERz (1934) niiden sisältävän runsaasti myös mangaania. SillanpäÄn ja LAKASEN (1966) aineiston suomalaisissa maissa oli liukoista mangaania keskimäärin $24.7 \mathrm{mg} / \mathrm{l}$, mitä tasoa tässäkin tutkimuksessa saadut pintamaan arvot edustavat. Sen sijaan pohjamaiden todetaan sisältäneen HANNERzin väitteen mukaisesti varsin runsaasti mangaania.

\section{Tiivistelmä}

Kyrönjoen valuma-alueelta kartoitettiin n. 26000 ha viljelymaata sulfaattimaiksi, mikä on $19 \%$ koko viljelyalasta. Pääosa $(80 \%)$ todetuista sulfaattimaista sijoittui korkeustasolle $15-45 \mathrm{~m}$ merenpinnasta.

Yli 600 maanäytteestä, jotka oli otettu muokkauskerroksesta, $50-70 \mathrm{~cm}: n$ kerroksesta ja pohjavedenpinnan alapuolelta tutkittiin rikki-, kalsium-, magnesium-, kalium-, rauta-, alumiini- ja mangaanipitoisuudet sekä $\mathrm{pH}$-arvo ja johtoluku. Paitsi rikkiä todettiin maiden sisältävän rautaa, alumiinia ja pohjamaakerroksessa myös mangaania runsaammin kuin suomalaisissa maissa yleensä. Näiden maiden pH-arvo oli normaalia alhaisempi ja johtoluku taas tavanomaista korkeampi.

Aerobisen keskikerroksen $(50-70 \mathrm{~cm})$ korkeimmat keskimääräiset rikki-, rauta- ja alumiinipitoisuudet sekä korkein johtoluku ja alhaisin $\mathrm{pH}$-arvo todettiin lieju- ja liejusaviryhmien maissa. Keskimääräiset mangaanipitoisuudet olivat korkeimmat anaerobisissa pohjamaanäytteissä.

Maan keskikerroksen pH-arvo oli sitä alhaisempi mitä enemmän maa sisälsi rikkiä, rautaa tai alumiinia. Rauta ja alumiini olivat selvässä positiivisessa vuorosuhteessa keskenään. Maan johtoluku nousi rikki-, rauta- tai aluminipitoisuuden kasvaessa. Johtoluvun kasvaessa maan $\mathrm{pH}$-luku aleni.

Kiitokset. MML Sylvi Soini suoritti maanäytteiden oton ja sulfaattimaiden rajaukset kartoille ja FM Tauno Tares tarkisti sulfaattirikin määritysmenetelmän sekä valvoi analyysien suoritukset Maantutkimuslaitoksella. Heidän osuudestaan tutkimuksessa lausun parhaat kiitokseni. 
Aarnio, B. 1924. Uber Salzböden (Alaunböden) des humiden Klimas in Finnland. Comptes Rendus Conf. Extraordinaire Agropédologique à Prague 1922. p. 186-192. Prague.

- , 1927. Etelä-Pohjanmaa. Agrogeologisia karttoja N:o 5. 83 p. Helsinki.

ANon. 1973. Selvitys Kyrönjoen edustan merialueen kalakuolemien syistä. Vesihallitus, Vaasan vesipiiri. $101 \mathrm{p}$.

Brinkman, R. \& Pons, L. J. 1973. Recognition and prediction of acid sulphate soil condition. Intern. Inst. Land Reclamation Improvement. Publ. 18. Vol. 1: 169-203.

Frosterus, B. 1914. Zur Frage nach der Einteilung der Böden in Nordwest-Europas Moränengebieten V. Geol. Komm. Finland Geotekn. Medd. 14:1-124.

HANnerz, E. 1934. Om så kallade alunajordar. 25 p. Luleå.

Kawalec, A. 1973. World distribution of acid sulphate soils. References and Map. Intern. Inst. Land Reclamation Improvement. Publ. 18. Vol. 1:292-295.

Kevie, W. van der. 1973. Physiography, classification, and mapping of acid sulphate soils. Intern. Inst. Land Reclamation Improvement. Publ. 18. Vol. 1:204-221.

Krvinen, E. 1938. Untersuchungen über die Eigenschaften der Gyttjaböden. Agrogeol, Julk. 48: $1-36$.

- - 1944. Aluna- eli sulfaattimaista. Maatal. tiet. Aikak. 16: 147-160.

Korкмan, J. 1973. Sulphur Status in Finnish cultivated soils. Selostus: Suomen viljelysmaiden rikkitila. Maatal.tiet. Aikak. 45: 121-215.

LAAKsonen, R. 1970. Vesistöjen veden laatu. Summary: Water quality in the water systems. Soil and Hydrotechn. Inv. 17: 1-132.

Mйкıтı́, О. 1968. Aluminium, extractable from soil samples by the acid acetate soil testing method. Selostus: Maan alumiinin liukenemisesta viljavuusnalyysin happamaan ammoniumasetaattiliuokseen. Maatal.tiet. Aikak. 16: 147-160.

Окко, М. 1967. The relation between raised shores and present land uplift in Finland during the past 8000 years. Ann. Acad. Sci. Fenn. A III. Geologica-Geographica 93: 1-59.

PURokoskı, P. 1956. Förekomst och föreningar av svavel in gyttjalera. Nord. Jordbruksforsk. $38: 263-266$.

- -1958 . Die schwefelhaltigen Tonsedimente in dem Flachlandgebiet von Liminka im Lichte chemischer Forschung. Selostus: Limingan tasankoalueen rikkipitoiset savisedimentit kemiallisen tutkimuksen valossa. Agrog. Publ. 70: 1-88.

- - 1959. Rannikkoseudun rikkipitoisista maista. Referat: Uber die schwefelhaltigen Böden an der Küste Finnlands. Agrog. Publ. 74: 1-27.

RAsmussen, K. 1961. Uorganiske svovlforbindelsers omsaetningar i jordbunden. Summary: Transformations of inorganic sulphur compounds in soil. 175 p. København.

Rickard, D. T. 1973. Sedimentary iron sulphide formation. Intern. Inst. Land Reclamation Improvement. Publ. 18. Vol. 1: 28-63.

Sillanpää, M. \& Lakanen, E. 1966. Readily soluble trace elements in Finnish soils. Selostus: Liukoisista hivenaineista Suomen maalajeissa. Ann. Agric. Fenn. 5: 298-304.

Wiklander, L., Hallgren, G. \& Jonsson, E. 1950. Studies on gyttja soils. III. Rate of sulfur oxidation. Kungl. Lantbr.högsk. Ann. 17:425-440.

Vuorinen, J. \& MÄкıтіE, O. 1955. The method of soil testing in use in Finland. Selostus: Viljavuustutkimuksen analyysimenetelmästä. Agrogeol. Publ. 63:1-44. 